\title{
Entomological survey and biodiversity conservation in the Madeleine Island Park of Senegal: Analeptes trifasciata (Coleoptera, Cerambycidae), a threat to the insular baobab
}

\author{
Saliou NIASSY ${ }^{1}$, Karamoko DIARRA $^{1 *}$, Abdoul A. NIANG ${ }^{2}$ and Alain COACHE ${ }^{4}$ \\ ${ }^{1}$ Department of Animal Biology, Faculty of Science and Applied Science, Cheikh Anta Diop, University of \\ Dakar, Box 5005, Senegal. \\ ${ }^{2}$ Laboratory of Terrestrial Invertebrates Zoology, Department of Animal Biology, IFAN Ch. A. Diop, Box 206, \\ Dakar, Senegal. \\ ${ }^{3}$ Observatoire et Conservatoire des Insectes du Sénégal, Résidence Nianing, villa ${ }^{\circ}$ 40, Nianing, Box. 1255 \\ Mbour, Senegal. \\ *Corresponding author,E-mail: karamoko.diarra@ucad.edu.sn
}

\begin{abstract}
A management program of biodiversity inventory and conservation was recently adopted for the rehabilitation of the Madeleine Island National Park (MINP). Entomological surveys were conducted between 2006 and 2009 to gather biological data on the biodiversity and to point out species of interest. Over 30 species of insects belonging mainly to Coleoptera, Orthoptera and Lepidoptera were collected and identified. The Baobab is one of the most important tree species of interest due to its dwarfism which is a source of curiosity for many scientists, visitors and tourists. A coleopteran pest Analeptes trifasciata (Cerambycidae) was found to be a vicious pest to the Baobab Adansonia digitata (Malvale: Bombacaceae). That Beetle was reported earlier in almost all West African countries as a threat to many tree species. This preliminary survey encourages a thorough inventory of the biodiversity and suggests a conservation strategy for major species such as the Baobab, by introducing a management tool to control the damages of A. trifasciata.
\end{abstract}

(c) 2011 International Formulae Group. All rights reserved.

Keywords: Insular, inventory, Adansonia, Analeptes, cerambycidae, Senegal.

\section{INTRODUCTION}

Since 1976, the Madeleine Island has got the status of a National Park (MINP) (GINGER, 2006) and belongs to the Sahelo soudanian area. The park is located between the isohyets 500 and $700 \mathrm{~mm}$, in the western side of Dakar. The ecosystem is similar to a humid zone and has an international importance. The MINP, mostly populated by nesting birds (Phaetons, Cormorants, Fou de bassan, Black Kite, Red-billed Hornbill, etc.), is a transit area for migratory birds for reproduction ecological shelter for fish species like white grouper, Epinephelus aeneus. The island hosts a rich biodiversity of animal (reptiles, insects and mammals), grasses, shrubs and very few trees. Over a hundred species of plants have been listed (Noba et al., 2007). 
Among the plant species, the Baobab Adansonia digitata is the only tree in the MINP and shows remarkable features of marine insular environment. There is a growing interest on those baobab specimens to that adaptation; nanism (dwarfism); crawling-baobab tree on the ground which is a spectacular source of attraction to many tourists and ecologists and therefore requires protection. It almost covers a large surface form of the valley upwards to the platform. Baobab trees are very important in Senegal. They represent the national emblematic seal, administrative stamps and food as well (Collière, 2002). On the other hand, few entomological studies have been conducted to assess the biodiversity in the MINP in prospect of adequate management measures for the conservation of the Baobab. Therefore, the aim of this entomological survey was to update the biodiversity data in the MINP and to establish the relations between the populations of insects and their habitats.

\section{MATERIALS AND METHODS}

\section{Geographical position}

The MINP is a volcanic complex of 3 small islands located at $3.5 \mathrm{~km}$ west from Dakar corresponding to $14^{\circ} 40^{\prime}$ '00" North and $17^{\circ} 40^{\prime} 00^{\prime}$ 'West. It is the smallest park in the world and covers a surface of 45 hectares with a typical insular ecosystem (GINGER, 2006). The topographical aspect is composed of a sloppy cliff followed by a platform with valleys. The vegetation is mainly dominated by herbaceous and very few shrubs.

\section{Insect collection and preservation}

This study was carried for a period of three years, mostly between October and December, after the rainy season. Other regular field trips were organized for more data collection during the rainy season. Various trapping techniques were used; catching by using hand nets, pitfall-traps were used to collect walking insects, acting mainly on the ground during the night. This type of trap can also help in the assessment of insect abundance. As for the pest attacking the Baobab Analeptes trifasciata, samples were directly picked from the tree. Specimens were preserved then in alcohol $90^{\circ}$ and labeled. Pierce traps were used for the collection of termites. The identification process of specimens was done at the Laboratory of Terrestrial Invertebrates Zoology, Department of Animal Biology, Fundamental Institute of Black Africa, Cheikh Anta Diop (IFANCh.A.Diop).

\section{RESULTS AND DISCUSSION Identification}

The entomological specimens collected from the island belong to 6 orders, 13 families and 36 species. There was a dominance of Orthoptera, Coleoptera and Lepidoptera (Table 1). Other species are still under identification procedure (Termites and bugs).

\section{Diversity and ecology}

The entomological diversity was more abundant during the rainy season which coincides with the period of herbaceous. The Coleoptera and Orthoptera orders were the most frequent in the park especially around the valley respectively $35 \%$ and $32 \%$ of the insect species (figure 1). The Orthoptera order is represented by grasshoppers that feed on grasses as primary plant predators. Kraussaria angulifera is the most represented grasshopper. Around the valley (talweg) whereby the density of grass is higher and more variable, Hieroglyphus daganensis and Diabolocantantops are also common. On the platform, very few of Orthoptera are present even though due to the scarcity of herbaceous. The platform of the island is mainly populated by Acrotylus sp. and Cataloipus sp.

The diversity of herbaceous (Poaceae) plants is the main reason that can explain that rich diversity of Orthoptera. Over a hundred plant species belonging to 87 plant families 
have been listed in the Park (GINGER, 2006; Noba, personal comm.). Since grasshoppers don't migrate for long distance (Greathead et al., 1989), many hypotheses explaining their high density can be proposed. The lack of specific predators can explain this high presence combined with the small area covered by grasses. Indeed, the island has a small presence of reptiles (snakes and turtles) that may probably feed with those insects. As for birds, they are more granivorus of fish predators. Therefore, they cannot be considered as real predators of Orthopterans. In that regard, the only one group that may interfere with the grasshoppers are beetles Tenebrionidae. This group is known to be a predator of insect eggs (Greathead et al., 1989). There is a very rich diversity of Coleoptera, especially Tenebrionidae and Cleridae.

The dry season characterized by a high presence of termites which still under identification process and beetle Tenebrionidae Thalpophilodes abbreviata abbreviata (Koch) eventually dwelling in track of Orthopteran eggs laid in the ground.

The Lepidoptera group was also represented with genus Colotis and Eurema. These species were found already in the Museum of IFAN. However, their abundance was not comparable to the one of grasshoppers and beetles. There were other minor groups Heteroptera, Odonata and Dictyoptera. The Dictyoptera are represented by the genus Mantis sp., an insect predator and Heteroptera are represented by Disdercus sp.

\section{Relationship insects-plants: impact of Analeptes trifasciata on the Baobab}

Many authors reported that the Baobab is a potential host-plant to many insect pests (Booth and Wickens, 1988; Wickens, 1982). The Cerambycidae are represented by the species Analeptes trifasciata (Fabricius, 1775) that feeds on baobabs causing severe damages. In the MINP, A. trifasciata constitutes the main pest of Baobabs. In Côte d'Ivoire, A. trifasciata was not found on Adansonia digitata but was described as a pest of Anacardiaceae plants although other hostplants have been reported: Sterculia tragantha (Sterculiacées), Spondias monbin (Anacardiaceae), Nauclea aesculenta (Rubiaceae) and Ficus capensis (Moraceae) (Brunck and Fabre, 1970). A closely related species Paranaleptes reticulata (Thoms.) has been described on Hibiscus, Kapok, Bougainvillea, Cotton, Acacia, Citrus and Ceiba pentandra (Chinea-Rivera, 1990; Collière, 2002; Duffey, 1957; Dwomoh et al., 2008; FAO, 2007; Hill, 1975; Tchibozo and Braet, 2004). The life cycle of $A$. trifasciata is typical: the stem tegument is sectioned in a way to prevent the sap to run. Consequently, the distal part of the branch dries out allowing thus the female to ovoposite on dry wood. Once the egg hatches, the larvae pierces the branch eat of wood as she grows all along the dry part. Damages are more serious during the rainy season which corresponds to the flowering stage and fruitage of the Baobabs in the island (Tchibozo and Braet, 2004). Over 10 mating adults of $A$. trifasciata are found per tree around October (end of rainy season).

A scrupulous inventory should be carried out to improve the biodiversity database. During our survey, we noticed the presence of termites and other insects. Other trapping systems such as sticky traps and Pierce traps should be used to increase the entomological database. This survey suggests the use of an integrated pest management approach mitigate the threat to the Baobab. The use of lure and pheromone traps can be adapted to the management program. Further programs on the impact of this pest on other Baobab tree in Senegal are recommended to avoid future outbreaks of this pest. 
Table 1: Entomological fauna collected in Madeleine Island National Park (Dakar, Senegal).

\begin{tabular}{|c|c|c|c|}
\hline Order & Family & Genus & Species \\
\hline \multirow{11}{*}{ Orthoptera } & \multirow{2}{*}{ Gryllidae } & Gryllus & Gryllus bimaculatus (de Geer, 1773) \\
\hline & & Brachytrypes & Brachytrypes megacephalus (Lefebvre 1827) \\
\hline & \multirow{9}{*}{ Acrididae } & Kraussaria & Kraussaria angulifera (Krauss, 1877) \\
\hline & & Sphingonotus & Sphingonotus savignyi savignyi (Saussure, 1884) \\
\hline & & Hieroglyphus & Hieroglyphus daganensis (Krauss, 1877) \\
\hline & & Cataloipus & Cataloipus cymbiferus (Krauss, 1877) \\
\hline & & Cataloipus & Cataloipus fuscocoeruleipes (Sjöstedt, 1923) \\
\hline & & Heteracris & Heteracris leani (Uvarov, 1941) \\
\hline & & Platypternodes & Platypternodes savannae (Uvarov, 1926) \\
\hline & & Diabolocatantops & Diabolocatantops axillaris axillaris (Thunberg, 1815) \\
\hline & & Tylotropidius & Tylotropidius gracilipes (Brancsik, 1895) \\
\hline \multirow{12}{*}{ Coleoptera } & Dermestidae & Dermestes & Dermestes maculatus De Geer, 1774 \\
\hline & Cerambycidae & Analeptes & Analeptes trifasciata (Fabricius, 1775) \\
\hline & Cleridae & Necrobia & Necrobia rufipes (De Geer, 1775) \\
\hline & \multirow{6}{*}{ Tenebrionidae } & Thalpophilodes & Thalpophilodes abbreviata dakarensis (Koch, 1943) \\
\hline & & Adesmia & Adesmia (Macradesmia) variolaris Olivier, 1795, \\
\hline & & Pachycera & Pachycera (Hyperops) tagenioides Eschscholtz, 1831 \\
\hline & & Gonocephalum & Gonocephalum (G.) duplegranatum Gridelli, 1948 \\
\hline & & Gonocephalum & Gonocephalum (G.) inquinatum inquinatum Sahlberg, 1823 \\
\hline & & Prodhilamus & $\begin{array}{l}\text { Prodhilamus ferrantei parallelus Ardoin = Prodhilamus brevicollis } \\
\text { parallelus Ardoin, } 1961\end{array}$ \\
\hline & Cetoniidae & Pachnoda & Pachnoda sp. \\
\hline & Meloidae & Mylabris sp. & Mylabris sp. \\
\hline & Curculionidae & Cyphocleonus & Cyphocleonus sp. \\
\hline
\end{tabular}


Table 2: Entomological fauna collected in Madeleine Island National Park (Dakar, Senegal).

\begin{tabular}{|c|c|c|c|}
\hline Order & Family & Genus & Species \\
\hline Dictyoptera & Mantidae & Mantis & Mantis religiosa,(Linnaeus, 1758) \\
\hline Odonata & & Trithemis & Trithemis annulata (Palisot de Beauvois, 1805) \\
\hline Heteroptera & & Disdercus & Disdercus sp. \\
\hline \multirow{8}{*}{ Lepidoptera } & \multirow{6}{*}{ Pieridae } & Eurema & Eurema brigitta (Boisduval, 1833) \\
\hline & & Colotis & Colotis danae eupompe Klug, 1829 \\
\hline & & Colotis & Colotis eucharis evarne (Fabricius, 1775) \\
\hline & & Colotis & Colotis spp (1 et 2$)$ \\
\hline & & Pinacopteryx & Pinacopteryx eriphia tritogenia (Klug, 1829) \\
\hline & & Belenois & Belenois creona creona Cramer, 1776 \\
\hline & Nymphalidae & Junonia & Junonia orithya madagascarensis (Linnaeus, 1764) \\
\hline & Danaidae & Danaus & Danaus chrysippus (Linné, 1758) \\
\hline
\end{tabular}

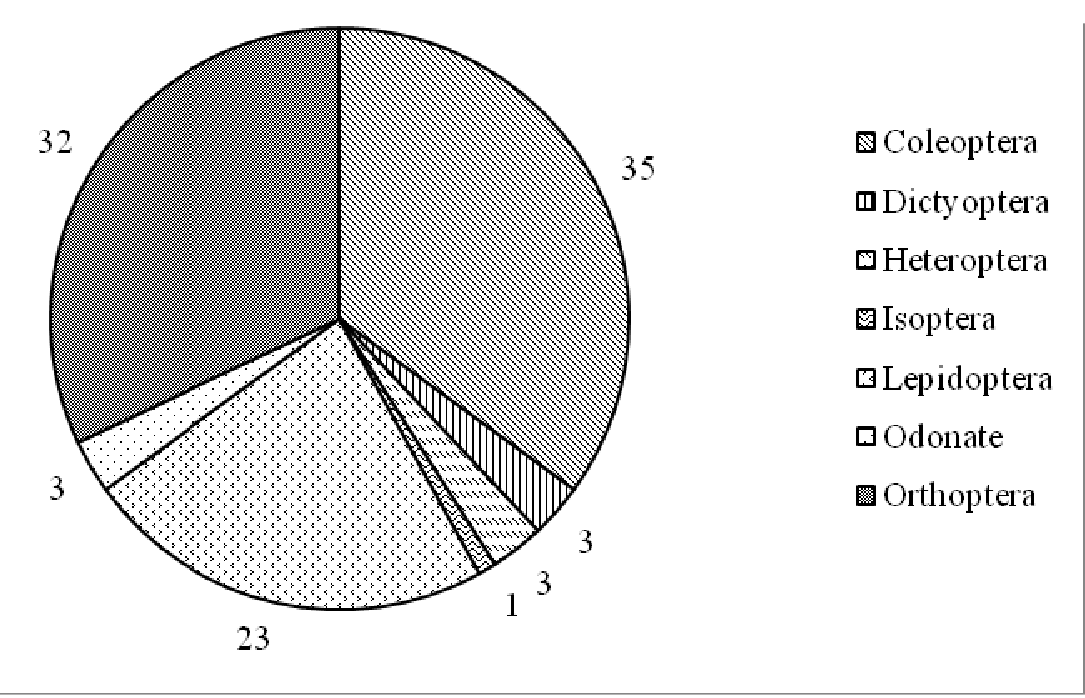

Figure 1 : Abundance (\%) of the entomological groups (order) in the Madeleine Island National Park. 


\section{ACKNOWLEGDMENTS}

The authors are very grateful to the National Park Direction of Senegal (Direction des Parcs Nationaux) through Dr. Lamine Kane and his staff for providing facilities and organizing trips to the park island.

\section{REFERENCES}

Booth FEM, Wickens GE. 1988. Non-timber uses of selected arid zone trees and shrubs in Africa. FAO, Rome.

Brunck F, Fabre JP. 1970. Note sur Analeptes trifasciata Coléoptère Cérambycide, grave ravageur d'Anacardium occidentale en Côte d'Ivoire. Revue Bois et Forêts des Tropiques, 134: 15-19.

Chinea-Rivera JD. 1990. Ceiba pentandra (L.) Gaertn. Ceiba, kapok, silk cotton tree. New Orleans, LA: U.S. Department of Agriculture, Forest Service: 4.

Collière P. 2002. La forêt de Baobabs (Adansonia digitata L.) de Nguékokh (Sénégal) : analyse des causes de la dégradation de la forêt et recherche de solutions: Rapport d'étude de la mission humanitaire réalisée au CIAF de Nguékokh (edn. Solidarité avec le Sénégal), Sénégal.

Duffey EAJ. 1957. A Monograph of the Immature Stages of African Timber Beetles (Cerambycidae). The. British Museum (Natural History) : London, UK.
Dwomoh EA, Ackonor JB, Afun JVK. 2008. Survey of insect species associated with cashew (Anacardium occidentale Linn.) and their distribution in Ghana. African $J$. Agric. Res., 3: 205-214.

FAO. 2007. Overview of forest pests: Working Paper FBS/16E (ed. by FHBW Papers) Food Agriculture Organization, Ghana, p. 21.

GINGER. 2006. Objectifs de gestion du Parc National des Iles de Madeleine: M0609.0008 (ed. by S.I.E.E).

Greathead DJ, Kooyman C, Launois-Luong MH, Popov GB. 1989. Les Ennemis Naturels des Criquets du Sahel. Collection Acridologie Opérationnelle. PRIFAS.

Hill D. 1975. Agricultural Insect Pests of the Tropics and their Control. Cambridge University Press; 371.

Tchibozo S, Braet Y. 2004. Les ravageurs des essences forestières du noyau central de la foret classe de la Lama (République du Benin): Note préliminaire et estimation de l'incidence du cérambycide Analeptes trifasciata (Fabricius, 1775), ravageur du Prunier mombin (Spondias mombin Linné, 1753) (Anacardiaceae). Bulletin S.R.B.E/K.B.V.E, 140: 151-156.

Wickens GE 1982 The Baobab - Africa's upside-down tree. Kew Bulletin, 37: 173209. 